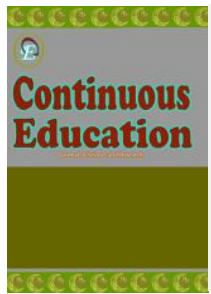

Continuous Education : Journal of Science and Research

Volume 2, Issue 1, March 2021

http://pusdikra-publishing.com/index.php/josr/home-free

\title{
Implementasi Manajemen Pembiayaan Pendidikan di MTs. Al-Manar Nurul Iman Sidamanik
}

Rizki Utami

Universitas Islam Negeri Sumatera Utara

Corresponding Author: @ rizkiutami712@gmail.com

\section{ABSTRACT}

Implementasi manajemen pembiayaan pendidikan di MTs. Al-Manar Nurul Iman Sidamanik. Penelitian ini merupakan penelitian deskriptif kualitatif. Tujuan penelitian ini adalah untuk mengetahui bagaimana perencanaan, pelaksanaan, pengawasan, serta evaluasi pembiayaan pendidikan di MTs. Al- Manar Nurul Iman Sidamanik. Hasil penelitian mengungkapkan bahwa: Perencanaan pembiayaan pendidikan di MTs. Al-Manar Nurul Iman Sidamanik dibuat pada Rencana Kegiatan dan Anggaran Madrasah (RKAM) yang dilakukan setiap awal tahun oleh

ARTICLE INFO

Article history:

Received

04 February 2021

Revised

01 April 2021

Accepted

07 April 2021 pihak sekolah. Setelah dirapatkan akan dikonsultasikan dengan pihak pengawas, kemudian dilakukan pengusulan dana Bantuan Operasional Sekolah (BOS) ke Kantor Wilayah Departemen Agama. Dalam pelaksanaan pembiayaan pendidikan dana diperoleh dari dana Bantuan Operasional Sekolah (BOS) yang dialokasikan untuk gaji pendidik dan tenaga kependidikan sebesar 50\%, Sarana dan Prasarana sebesar 30\% dan untuk Alat Tulis Kantor (ATK) sebesar 20\%. Serta diperoleh dari dana Komite yang dialokasikan untuk tunjangan jabatan, kegiatan siswa, kebersihan sekolah, Alat Tulis Kantor (ATK), dan transport. Pengalokasian dana tersebut akan dicatat dalam bentuk Laporan Pertanggungjawaban (LPJ) maupun buku Sumbangan Pembinaan Pendidikan (SPP) dan kas yang akan dipertanggungjawabkan oleh Kepala Madrasah. Untuk pengawasan pembiayaan pendidikan dilakukan oleh pihak internal dan eksternal Madrasah pada pemasukan dan pengeluaran dana. Kemudian, evaluasi pembiayaan pendidikan dilakukan oleh pihak Madrasah secara berkala untuk manilai, memantau dan melaporkan apakah penggunaan anggaran sudah sesuai dengan rencana.

Keywords

Implementasi, Manajemen, Pembiayaan, Pendidikan

Rizki Utami. (2021). Implementasi Manajemen Pembiayaan Pendidikan

How to cite Education, 2(1). 47-60. 10.51178/ce.v2i1.186

\section{PENDAHULUAN}

Peraturan Pemerintah (PP) Republik Indonesia No. 19 Tahun 2005 Tentang Standar Nasional Pendidikan, pada pasal 2 ayat 1 dijelaskan bahwa terdapat 8 standar Nasional Pendidikan, yaitu: 1) Standar Isi; 2) Standar Proses; 3) Standar Kompetensi Lulusan; 4) Standar Pendidik dan Tenaga Kependidikan; 5) Standar Sarana dan Prasarana; 6) Standar Pengelolaan; 7) Standar Pembiayaan; dan 8) Standar Penilaian Pendidikan (Sikdisnas, 2015). 
Pemerintah telah menetapkan 8 standar tersebut sebagai acuan untuk menciptakan pendidikan yang berkualitas. Standar pembiayaan pendidikan memiliki peran yang sangat penting dalam mencapai tujuan tersebut. Dapat dikatakan tanpa adanya biaya, segala aktivitas pendidikan tidak akan dapat terlaksana secara efektif dan efisien.

Dalam penyelenggarakan pembiayaan pendidikan harus pula didukung dengan kemampuan manajemen yang layak, dengan memberdayakan fungsifungsinya yang dirumuskan oleh George R. Terry yang meliputi Perencanaan, Pengorganisasian, Pelaksanaan dan Pengawasan (Terry \& Rue, 2010). Hal ini sesuai dengan amanah Undang-Undang Nomor 17 Tahun 2003 Tentang Keuangan Negara, pada penjelasan pasal 3 ayat 1 yang disebutkan bahwa: Setiap penyelenggara negara wajib mengelola keuangan negara secara tertib, taat kepada peraturan perundang-undangan, efisien, ekonomis, efektif, transparan dan bertanggung jawab dengan memperhatikan rasa keadilan dan kepatutan. Pengelolaan dalam ayat ini mencakup keseluruhan kegiatan perencanaan, penguasaan, penggunaan, pengawasan dan pertanggungjawaban. Sejalan dengan pendapat Matin yang menyatakan bahwa: "Manajemen pembiayaan pendidikan terdiri dari perencanaan anggaran, pelaksanaan anggaran, akuntansi berikut pertanggungjawaban keuangan pendidikan, serta pemeriksaan dan pengawasan anggaran" (UU Republik Indonesia, n.d.).

Proses perencanaan merupakan langkah awal kegiatan manajemen dalam setiap organisasi, karena melalui perencanaan ini ditetapkan apa yang akan dilakukan, kapan melakukannya, dan siapa yang akan melakukan kegiatan tersebut. Perencanaan merupakan alat untuk menganalisis segala kebutuhan sekolah baik itu satu tahun maupun berpuluh tahun berikutnya. Oleh karena itu, perlu adanya skala prioritas terhadap kebutuhan sekolah dan perlu memperhatikan kembali akan tersedianya waktu, tenaga, dan jumlah dana yang tersedia secara komprehensif (Akdon, 2015).

Dalam melaksanakan anggaran pendidikan, hal yang perlu dilakukan adalah pembukuan (accounting). Dalam UU No. 28 Tahun 2007 Pasal 1 ayat 29, pembukuan adalah suatu proses pencatatan yang dilakukan secara teratur untuk mengumpulkan data dan informasi keuangan yang meliputi harta, kewajiban, modal, penghasilan dan biaya serta jumlah harga perolehan dan penyerahan barang atau jasa, yang dittutup dengan menyusun laporan keuangan berupa neraca dan laporan laba rugi untuk periode tahun pajak tersebut. Segala bentuk penerimaan dan pengeluaran dana harus dicatat dalam pembukuan, tujuan dilakukannya pembukuan tersebut adalah supaya dapat membuat suatu laporan keuangan dan penggunaannya yang jujur dan dapat 
dipertanggungjawabkan. Laporan yang dibuat harus disajikan dengan sejelas mungkin agar tidak terjadi kekeliruan.

Pengawasan ini diharapkan dapat mengetahui sampai dimana tingkat efektivitas dan efisiensi dari penggunaan sumber dana yang tersedia. Pengawasan adalah suatu kegiatan untuk mendapatkan kepastian tentang pelaksanaan program atau pelaksanaan yang sedang atau telah dilakukan sesuai dengan rencana yang telah ditentukan. Kegiatan pengawasan pada dasarnya untuk membandingkan kondisi yang ada dengan yang seharusnya terjadi (Kurniadin \& Machali, 2010). Jika dikaitan dengan pembiayaan pendidikan di sekolah, pengawasan merupakan proses untuk memantau segala pengelolaan pembiayaan di sekolah apakah telah dialokasikan dan dimanfaatkan dengan efektif dan efisien dalam program kegiatan yang mendukung pencapaian tujuan lembaga pendidikan.

Menurut (Djaali \& Muljono, 2004), evaluasi adalah suatu proses menilai sesuatu berdasarkan kriteria atau tujuan yang telah ditetapkan yang selanjutnya diikuti dengan pengembangan keputusan atas objek yang di evaluasi. Selanjutnya menurut (Mutrofin, 2010) evaluasi adalah suatu kegiatan sistematis yang dilaksanakan untuk membantu audiensi agar dapat mempertimbangkan dan meningkatkan nilai suatu program atau kegiatan.

Hasil observasi pendahuluan yang dilakukan oleh peneliti di MTs. AlManar Nurul Iman Sidamanik pada tanggal 2 November 2019 menunjukkan bahwa seluruh pembiayaan yang ada di sekolah tersebut berasal dari dana komite yang diberikan oleh orang tua siswa dan dana Bantuan Operasional Sekolah (BOS) dari pemerintah. Yang berwenang mengatur uang atau dana tersebut adalah kepala madrasah, yang dibantu oleh bendahara madrasah dan kepala tata usaha madrasah.

Bendahara madrasah mengelola dana komite yang berasal dari orang tua siswa. Dana komite yang diberikan oleh orang tua siswa di MTs. Al-Manar berbeda-beda tingkatan. Contohnya, jika ekonomi orang tua tergolong mampu, maka dana komite yang diberikan sebesar Rp 25.000, jika siswa tergolong anak yatim/piatu, dana komite yang diberikan sebesar Rp 20.000, dan jika siswa tergolong anak yatim piatu dan yang tidak mampu, maka akan di geratiskan untuk dana komitenya. Dana tersebut akan dialokasikan untuk kegiatan siswa, tambahan gaji guru yang mengajar ekstra kulikuler, tunjangan jabatan, serta untuk penerimaan siswa baru. Sedangkan kepala tata usaha mengelola dana Bantuan Operasional Sekolah (BOS). Dana Bantuan Operasional Sekolah (BOS) yang akan diterima adalah berdasarkan pada jumlah siswa yang ada di sekolah dikali dengan RP 1.000.000, jumlah tersebutlah yang akan diterima oleh pihak sekolah dalam kurun waktu satu tahun. Dana BOS tersebut tidak diterima 
secara sekaligus, melainkan setiap 3 bulan sekali (triwulan) atau 4 kali dalam setahun. Ketentuan penggunaan dana BOS tersebut adalah dialokasikan untuk gaji guru sebanyak 50\%, ATK $20 \%$ dan dialokasikan untuk pemenuhan sarana dan prasarana sebanyak $30 \%$.

Kondisi pembiayaan pendidikan di MTs. Al-Manar Nurul Iman yang kurang memadai untuk memenuhi seluruh kebutuhan operasional sekolah mengharuskan pemimpin, bendahara, dan kepala tata usaha untuk memiliki kemampuan manajemen yang lebih baik dalam mengelola dana sekolah mulai dari perencanaan anggaran, pelaksanaan anggaran, pengawasan anggaran hingga pengevaluasian agar alokasi dana terarah dengan efektif dan efisien. Fakta tersebut memperlihatkan bahwa sangat dibutuhkannya manajemen keuangan yang baik, agar dapat memaksimalkan dana yang dimiliki untuk memenuhi segala kebutuhan operasional sekolah yang bermanfaat dalam menunjang proses belajar mengajar tetap berlangsung secara efektif untuk mencapai tujuan sekolah. Berdasarkan penjelasan tersebut, peneliti membahas tentang "Implementasi Manajemen Pembiayaan Pendidikan di MTs. Al-Manar Nurul Iman Sidamanik".

\section{METODE PENELITIAN}

Pendekatan penelitian yang digunakan dalam penelitian ini adalah pendekatan metode penelitian deskriptif kualitatif. Penelitian deskriptif kualitatif adalah penelitian yang menggambakan atau melukiskan objek penelitian berdasarkan fakta-fakta yang tampak atau sebagaimana adanya (Nawawi \& Martini, 1996). Penelitian ini dilaksanakan di MTs. Al-Manar Nurul Iman yang berlokasi di Jl. Besar Sidamanik, Kec. Sidamanik, Kab. Simalungun Provinsi Sumatera Utara yang berada dibawah naungan Yayasan Pendidikan AMNI. Dimulai tanggal 1 Maret 2020 sampai dengan 25 Juli 2020. Subjek penelitian adalah sumber utama data penelitian, yaitu data mengenai variabelvariabel yang diteliti (Sugiyono, 2020). Yang menjadi subjek dalam penelitian ini antara lain adalah Kepala Madrasah, Bendahara, dan Kepala Tatat Usaha MTs. Al-Manar Nurul Iman. Prosedur pengumpulan data melalui observasi, wawancara mendalam dan dokumentasi.

\section{HASIL PENELITIAN DAN PEMBAHASAN}

\section{Perencanaan Pembiayaan Pendidikan}

Manajemen pembiayaan pendidikan tidak terlepas dari penyusunan Rencana Anggaran Pendapatan dan Belanja Sekolah (RAPBS). Landasan dasar dalam pembuatan RAPBS meliputi sumber pendapatan dan pengeluaran. Perencanaan pembiayaan pendidikan atau Rencana Anggaran Pendapatan dan 
Belanja Sekolah (RAPBS) adalah anggaran terpadu antara penerimaan dan penggunaan dana serta pengelolaannya dalam memenuhi seluruh kebutuhan sekolah selama satu tahun pelajaran berjalan. Dimana sumber dananya berasal dari pemerintah pusat, pemerintah daerah, masyarakat, dan orang tua/wali peserta didik. Sumber dana perolehan dan pemakaian dana dipadukan dengan kondisi objektif kepentingan sekolah dan penyandang dana (Nata, 2003).

Berdasarkan teori di atas, perencanaan pembiayaan pendidikan di MTs. Al-Manar Nurul Iman mengacu pada Rencana Kegiatan dan Anggaran Madrasah (RKAM). RKAM ini difungsikan untuk menaksir kebutuhan biaya yang diperlukan, jumlah dana yang akan diperoleh, dan rincian pengeluaran beserta kegiatanya. Seperti yang diungkapkan oleh Nanang Fattah bahwa fungsi penganggaran atau perencanaan adalah sebagai alat penaksir, sebagai alat otorisasi pengeluaran dana, serta sebagai alat efisiensi, yakni dari segi pengendalian jumlah anggaran yang didasarkan atas angka-angka yang standar dibandingkan dengan realisasi biaya yang melebihi atau kurang dapat dianalisis ada tidaknya pemborosan atau penghematan (Fattah, 2002).

Tabel 1. Rencana Kegiatan dan Anggaran Madrasah (RKAM) MTs. Al-Manar Nurul Iman Tahun Ajaran 2019/2020

\begin{tabular}{|c|l|c|c|l|r|}
\hline No. & Penerimaan & $\begin{array}{c}\text { Jumlah } \\
\text { Dana (Rp) }\end{array}$ & No. & Pengeluaran & $\begin{array}{c}\text { Jumlah } \\
\text { Dana (Rp) }\end{array}$ \\
\hline 1 & $\begin{array}{l}\text { Dana BOS } \\
\begin{array}{l}8 \quad \mathrm{x} \text { Rp. } \\
1.000 .000\end{array}\end{array}$ & 89.000 .000 & 1 & $\begin{array}{l}\text { Pengembangan } \\
\text { Kompetensi } \\
\text { Lulusan }\end{array}$ & 8.800 .000 \\
\hline & & 2 & $\begin{array}{l}\text { Pengembangan } \\
\text { Standar Isi }\end{array}$ & 7.000 .000 \\
\hline & 3 & $\begin{array}{l}\text { Pengembangan } \\
\text { Standar Proses }\end{array}$ & 10.000 .000 \\
\hline & 4 & $\begin{array}{l}\text { Pengembangan } \\
\text { Pendidik Dan } \\
\text { Tenaga } \\
\text { Kependidikan }\end{array}$ & 24.000 .000 \\
\hline & 5 & $\begin{array}{l}\text { Pengembangan } \\
\text { Sarana Dan } \\
\text { Prasarana } \\
\text { Sekolah }\end{array}$ & 14.700 .000 \\
\hline & 6 & $\begin{array}{l}\text { Pengembangan } \\
\text { Standar } \\
\text { Pengelolaan }\end{array}$ & 12.500 .000 \\
\hline
\end{tabular}




\begin{tabular}{|c|c|c|c|c|c|}
\hline & & & 7 & $\begin{array}{l}\text { Pengembangan } \\
\text { Standar } \\
\text { Pembiayaan }\end{array}$ & 5.000 .000 \\
\hline & & & 8 & $\begin{array}{l}\text { Pengembangan } \\
\text { Dan } \\
\text { Implementasi } \\
\text { Sistem } \\
\text { Penilaian }\end{array}$ & 7.000 .000 \\
\hline \multirow[t]{6}{*}{2} & $\begin{array}{l}\text { Dana } \\
\text { Komite } \\
89 \quad \times \quad R p \\
25.000 \times 12\end{array}$ & 26.700 .000 & 1 & $\begin{array}{l}\text { Tunjangan } \\
\text { jabatan } \\
\text { Rp } 210.000 \times 12\end{array}$ & 2.520 .000 \\
\hline & & & 2 & ATK & 2.000 .000 \\
\hline & & & 3 & Transport & 1.500 .000 \\
\hline & & & 4 & Kegiatan Siswa & 6.000 .000 \\
\hline & & & 5 & $\begin{array}{l}\text { Kebersihan } \\
\text { Sekolah }\end{array}$ & 1.500 .000 \\
\hline & Total & 115.700 .000 & & & 102.520 .000 \\
\hline
\end{tabular}

Pada tabel RKAM MTs. Al-Manar Nurul Iman Sidamanik, sumber dana yang dimiliki berasal dari pemerintah berupa dana Bantuan Operasional Siswa (BOS) dan dari Orang tua/wali siswa berupa dana Komite atau yang disebut juga dana SPP. Dana BOS yang diterima dalam satu tahun sesuai dengan jumlah siswa yang ada di Madrasah pada satu tahun ajaran. Dana BOS akan dialokasikan pada 8 Standar Nasional Pendidikan, yaitu standar isi, standar proses, standar kompetensi lulusan, standar pendidik dan tenaga kependidikan, standar sarana dan prasarana, standar pengelolaan, standar pembiayaan dan standar penilaian.

Sedangkan untuk dana Komite, dalam perencanaannya dana akan dihitung berdasarkan pada jumlah siswa dalam status normal, artinya tidak tergolong yatim, piyatu atau tidak mampu. Dana komite akan dialokasikan untuk tunjangan jabatan, ATK, transport siswa maupun tata usaha untuk urusan ke Depag, kebersihan sekolah seperti babat rumput, serta untuk kegiatan siswa seperti latihan drum band, MTQ, dan lain sebagainya. Anggaran dana untuk ATK sudah ada dari BOS, namun untuk mengantisipasi keterlambatan dalam pencairan dana BOS maka pihak Madrasah berinisiatif untuk membuat anggaran ATK pada dana Komite juga.

Pembuatan rencana anggaran ini dilakukan pada rapat yang dilakukan setiap awal tahun dengan melibatkan Kepala Madrasah, Bendahara, Tata 
Usaha, Dewan Guru dan Komite sekolah. Proses perencanaan anggaran ini membahas dana yang akan diperoleh, menganalisis kebutuhan, serta pengeluaran dalam kurun waktu satu tahun kedepan. Prosedur untuk dapat menerima dana dilakukan dengan beberapa tahapan, yaitu mulanya mengadakan rapat, setelah hasil rapat perencanaan biaya Madrasah selesai dibuat selanjutnya akan di konsultasikan kepada pengawas madrasah dari Departemen Agama terlebih dahulu. Setelah disetujui pengawas, kemudian dilakukan pengusulan dana Bantuan Operasional Sekolah (BOS) dengan menyertakan Rencana Kegiatan dan Anggaran Madrasah (RKAM) kepada Kantor Wilayah Departemen Agama untuk dipertimbangkan dan disahkan. Namun RKAM yang disertakan hanya menyangkut dana BOS dan melepaskan dana Komite untuk menghindari dari adanya kalimat yang mengatakan Madrasah melakukan pungutan liar (pungli).

Penjelasan di atas sejalan dengan yang diungkapkan oleh (Minarti, 2011), pada tahap perencanaan analisis kebutuhan pengembangan sekolah dalam kurun waktu tertentu menjadi fokus utama yang perlu diperhatikan. Kebutuhan dalam satu tahun anggaran, lima tahun, sepuluh tahun, bahkan dua puluh lima tahun. Serta didukung dengan pendapat B. Suryosubroto yang menjelaskan perencanaan adalah pemilihan dari sejumlah alternatif tentang penetapan prosedur pencapaian, serta perkiraan sumber yang dapat disediakan untuk mencapai tujuan tersebut. Yang dimaksud dengan sumber meliputi sumber manusia, material, uang dan waktu (Suryosubroto, 2010).

\section{Pelaksanaan Pembiayaan Pendidikan}

Pelaksanaan keuangan sekolah secara garis besar dikelompokkan dalam dua kegiatan yakni penerimaan dan pengeluaran:

1. Penerimaan. Penerimaan keuangan sekolah dari sumber-sumber dana perlu dibukukan berdasarkan prosedur pengelolaan yang selaras dengan ketetapan yang disepakati, baik berupa konsep teoritis maupun peraturan pemerintah;

2. Pengeluaran. Pengeluaran sekolah berhubungan dengan pembayaran keuangan sekolah untuk pembelian beberapa sumber atau input dari proses sekolah seperti tenaga administrasi, guru, bahan-bahan, perlengkapan, dan fasilitas (Mulyasa, 2009).

Sujari Rahmanto, sumber-sumber keuangan sekolah dapat diperoleh melalui beberapa sumber, yaitu: a) sumber dana dari pemerintah pusat dan daerah; b) sumber dana dari orang tua/wali murid; c) sumber dana dari masyarakat; d) sumber dana dari lulusan; e) sumber dana dari anggota kegiatan; dan f) sumber dana dari kegiatan wirausaha lembaga pendidikan (Rahmanto, 2019). 
Penerimaan dana yang diperoleh oleh MTs. Al-Manar Nurul Iman Sidamanik berasal dari pemerintah dan dari orang tua/wali siswa. Dana dari pemerintah berupa dana Bantuan Operasional Sekolah (BOS) dimana dana tersebut diperoleh oleh Madrasah setiap tiga bulan sekali (triwulan), namun baru bisa dicairkan dananya pada dua kali triwulan. Dana BOS yang diterima sesuai dengan jumlah siswa yang dimiliki Madrasah dikali dengan anggaran dana BOS per siswa yang telah ditetapkan oleh Departemen Agama untuk tingkat MTs, yaitu sebesar Rp 1.000.000. Untuk memperoleh dana BOS ini, pihak Madrasah akan membuat usulan dana yang diserahkan setiap dua triwulan juga. Hal ini berdasarkan pada peraturan baru yang telah ditetapkan oleh pemerintah. Pengusulan dana BOS ini akan menyertakan surat permohonan pencairan dana, daftar siswa yang dibebaskan dari segala jenis pungutan (jika ada), surat tanggungjawab mutlak, pernyataan jumlah siswa, surat kebenaran nomor rekening yang dilampiri fotocopy buku rekening aktif, surat perjanjian kerjasama yang sudah di tandatangani PPK dan Kepala Madrasah, surat Pernyataan Tanggung Jawab Belanja (STJB) pada pencairan tahap kedua, RKAM, dan kuitansi penerimaan yang telah ditandatangani Kepala Madrasah. Sedangkan untuk dana Komite yang diperoleh, berdasarkan pada jumlah siswa dan statusnya. Siswa yang berstatus/tergolong dalam kondisi normal artinya mampu dan masih memiliki orang tua lengkap, uang komitenya sebesar Rp 25.000. kemudian untuk yang tergolong yatim/piyatu komite yang dibayarkan sebesar Rp 20.000. sedangkan untuk siswa yang tergolong yatim piyatu atau tidak mampu, maka akan digratiskan uang komitenya.

Tabel 2. Laporan Pertanggungjawaban pengelolaan Dana BOS Periode Januari-Maret Tahun Anggaran 2020

\begin{tabular}{|c|l|r|r|}
\hline No. & \multicolumn{1}{|c|}{ Uraian } & Jumlah (Rp) & \multicolumn{1}{|c|}{$\begin{array}{c}\text { Penggunaan } \\
\text { Dana }\end{array}$} \\
\hline 1 & Penarikan dana BOS & 22.276 .920 & \multicolumn{1}{c|}{} \\
\hline 2 & $\begin{array}{l}\text { Pembayaran Honor guru bulan } \\
\text { Januari-Maret 2020 }\end{array}$ & 11.460 .000 & 11.460 .000 \\
\hline 3 & $\begin{array}{l}\text { Pembayaran uang ujian } \\
\text { semeter dan UAMBN TP } \\
2019 / 2020\end{array}$ & 675.000 & 675.000 \\
\hline 4 & Belanja ATK Januari & 2.611 .920 & 2.611 .920 \\
\hline 5 & \begin{tabular}{l} 
Pembelian kursi siswa Napoly \\
\hline 6
\end{tabular} & 900.000 & 900.000 \\
\hline 7 & $\begin{array}{l}\text { Pembelian 2 buah meja guru } \\
\text { dan siswa }\end{array}$ & 980.000 & 980.000 \\
\hline
\end{tabular}


Journal Continuous Education

Volume 2, Issue 1, March 2021

Page 47-60

\begin{tabular}{|c|l|r|r|}
\hline 8 & Perawatan sekolah & 1.200 .000 & 1.200 .000 \\
\hline 9 & $\begin{array}{l}\text { Biaya internet bulan Januari- } \\
\text { Maret }\end{array}$ & 2.100 .000 & 2.100 .000 \\
\hline 10 & $\begin{array}{l}\text { Honor penarikan dana BOS } \\
\text { untuk Kepala Sekolah dan } \\
\text { Bendahara }\end{array}$ & 200.000 & 200.000 \\
\hline 11 & $\begin{array}{l}\text { Transport pengawas ujian } \\
\text { semester genap }\end{array}$ & 550.000 & 550.000 \\
\hline 12 & Pembelian 1 unit CPU & 800.000 & 800.000 \\
\hline 13 & Pengelolaan laporan dana BOS & 350.000 & 350.000 \\
\hline & Total & 22.276 .920 & 22.276 .920 \\
\hline
\end{tabular}

Laporan Pertanggungjawaban (LPJ) pengelolaan dana BOS periode Januari-Maret Tahun Anggaran 2020 merupakan laporan penerimaan dan pengeluaran dana BOS yang diterima pada triwulan pertama. Laporan tetap dibuat setiap triwulan meskipun penyerahannya dua kali triwulan. Pada tabel tersebut terlihat bahwa penerimaan dana sebesar Rp 22.276.920. Pengalokasiannya lebih besar pada penggajian Guru karena memang memiliki $50 \%$ bagian dari dana BOS. 30\% untuk sarana dan prasarana seperti pembelian meja, kursi, CPU, pembayaran internet dan sebagainya. Selanjutnya bagian terkecil adalah untuk ATK sebesar 20\%. Dana BOS yang telah diterima Madrasah akan dialokasikan seluruhnya untuk memenuhi kebutuhan tanpa menyisahkan saldo.

Tabel 3. Perincian penggunaan dana Komite atau disebut dengan Sumbangan Pembiayaan Pendidikan (SPP) bulan Januari-Maret Tahun 2020

\begin{tabular}{|c|l|r|r|r|}
\hline No. & \multicolumn{1}{|c|}{ Uraian } & Debit & Kredit & \multicolumn{1}{c|}{ Saldo } \\
\hline 1 & $\begin{array}{l}\text { Saldo kas bulan } \\
\text { Desember }\end{array}$ & - & - & 5.217 .000 \\
\hline 2 & SPP bulan Januari & 1.320 .000 & - & 6.537 .000 \\
\hline 3 & Babat rumput & - & 160.000 & 6.377 .000 \\
\hline 4 & Kapur tulis 10 kotak & - & 70.000 & 6.307 .000 \\
\hline 5 & Air galon isi ulang $x 4$ & - & 20.000 & 6.287 .000 \\
\hline 6 & Transport KTU & - & 200.000 & 6.087 .000 \\
\hline 7 & Honor bulan Desember & - & 190.000 & 5.897 .000 \\
\hline 8 & SPP bulan Februari & 540.000 & - & 6.437 .000 \\
\hline 9 & Air galon isi ulang $x 2$ & - & 10.000 & 6.427 .000 \\
\hline 10 & Pengawas sekolah & - & 100.000 & 6.327 .000 \\
\hline 11 & Sumbangan MTQ & - & 300.000 & 6.027 .000 \\
\hline 12 & Snack pengawas & - & 40.000 & 5.987 .000 \\
\hline
\end{tabular}


Journal Continuous Education

Volume 2, Issue 1, March 2021

Page 47-60

\begin{tabular}{|c|l|r|r|r|}
\hline 13 & Babat rumput & - & 160.000 & 5.827 .000 \\
\hline 14 & Honor bulan Januari & - & 190.000 & 5.637 .000 \\
\hline 15 & SPP bulan Maret & 670.000 & - & 6.307 .000 \\
\hline 16 & Gembok sekolah & - & 20.000 & 6.287 .000 \\
\hline 17 & $\begin{array}{l}\text { Gebyar pendidikan di } \\
\text { SMAN 1 Sidamanik }\end{array}$ & - & 400.000 & 5.887 .000 \\
\hline 17 & Honor bulan Februari & - & 190.000 & 5.697 .000 \\
\hline & & 2.530 .000 & 3.167 .000 & 5.697 .000 \\
\hline
\end{tabular}

Tabel tersebut merupakan laporan penerimaan dan pengeluaran dana Komite atau disebut dengan Sumbangan Pembiayaan Pendidikan (SPP) bulan Januari-Maret Tahun 2020 yang dirincikan di dalam buku kas. Pada tabel tersebut terlihat bahwa penerimaan yang diterima setiap bulannya tidak konstan, hal ini dikarenakan siswa yang sering melakukan penunggakan dalam membayar uang Komite. Dana Komite akan dialokasikan untuk tunjangan jabatan, seperti Kepala Sekolah, TU, Bendahara, WKM, dan wali kelas. Kemudian dialokasikan untuk transport KTU, kegiatan siswa seperti MTQ, ATK dan sebagainya. Dalam pengalokasian dana Komite ini tidak dipergunakan habis seluruhnya, tetapi meninggalkan saldo yang dapat dipergunakan untuk bulan-bulan berikutnya serta untuk antisipsi jika ada kebutuhan mendadak.

Pelaksanaan alokasi dana ini tidak selalu berjalan sesuai dengan rencana, dikarenakan dapat terjadinya kebutuhan yang mendadak seperti bencana alam, kemalangan atau sakit dan sebagainya. Dalam perencanaan hal-hal tersebut tidak desertakan. Maka pengalihan alokasi dana bisa terjadi jika kebutuhan yang muncul benar-benar harus diutamakan serta harus memenuhi syarat danketentuan untuk dialihkan, seperti dengan surat pernyataan pengalihan dana yang di tandatangani oleh Kepala Sekolah. Hal ini juga dikarenakan Kepala Sekolah merupakan penanggungjawab terhadap seluruh pengelolaan dana, baik penerimaan maupun pengeluarannya.

\section{Pengawasan Pembiayaan Pendidikan}

Pengawasan merupakan merupakan proses memantau berbagai program lembaga. Tujuannya untuk menetapkan tujuan yang dapat diwujudkan secara nyata dan memperbaiki semua penyimpangan (Bafadal, 2013). Dalam pengawasan pembiayaan pendidikan di MTs. Al- Manar Nurul Iman Sidamanik, yang dipantau adalah penerimaan dan pengalokasian dana Madrasah. Tujuannya agar pemanfaatan dana dapat dilakukan secara efektif dan efisien serta meminimalisir penyalahgunaan dana yang bersifat pemborosan serta dapat menyebabkan dana yang dimiliki habis tanpa memberikan manfaat. Pengawasan pembiayaan pendidikan dilakukan oleh 
dua pihak, yaitu pihak internal dan eksternal. Pihak internal terdiri dari Kepala Madrasah dan Komite Sekolah sedangkan pihak eksternalnya berasal dari Departemen Agama Kabupaten Simalungun.

(T. Hani Handoko, 2012) menyatakan bahwa terdapat tiga tipe dasar pengawasan, yaitu pengawasan pendahuluan, pengawasan yang dilakukan berbarengan dengan pelaksanaan kegiatan dan pengawasan umpan balik.

1. Pengawasan Pendahuluan, pengawasan pendahuluan ini dapat diterapkan oleh pihak sekolah untuk mengantisipasi masalah-masalah yang kemungkinan muncul dan menyimpang dari tujuan awal.

2. Pengawasan yang dilakukan berbarengan dengan pelaksanaan kegiatan, pengawasan ini dilakukan disaat kegiatan sedang berlangsung, disaat melihat penyimpangan terjadi maka pihak sekolah langsung berupaya untuk menyelesaaikan permasalahan yang terjadi.

3. Pengawasan umpan balik, pengawasan ini dilakukan untuk mengukur hasil dari kegiatan penganggaran yang telah dilaksanakan.

Pada pengawasan pembiayaan pendidikan di MTs. Al-Manar dilakukan berbarengan dengan pelaksanaan kegiatan, biasanya ini dilakukan oleh pihak internal Madrasah yang berkecimpung langsung hampir setiap hari di Madrasah. Sehingga dapat melihat pelaksanaan alokasi dan penerimaan dana secara langsung sekaligus dapat menilik apakah ada penyimpangan, jika ada maka akan diberikan peringatan dan pengarahan untuk memperbaikinya. Sedangkan untuk pihak dari eksternal biasanya melakukan pengawasan dengan tipe umpan balik, dimana pengawas akan mengukur hasil kegiatan penganggaran yang telah dilakukan. Pihak pengawas eksternal melakukan pengawasan sebanyak empat kali dalam satu semester untuk melihat apakah pelaksanaan alokasi dana sesuai dengan rencana atau tidak. Pihak pengawas eksternal hanya mengawasi dana BOS saja, dikarenakan untuk dana Komite pertanggungjawabannya hanya langsung pada Kepala Madrasah sehingga pengawasannya juga hanya dilakukan oleh Kepala Madarasah dan Komite Sekolah.

\section{Pengevaluasian Pembiayaan Pendidikan}

Evaluasi pada pembiayaan pendidikan di MTs. Al-Manar Nurul Iman dilakukan oleh Kepala Madrasah. Evaluasi dilakukan secara berkala dalam kurun waktu tiga bulan sekali. Tujuan dilakukannya evaluasi adalah untuk memperoleh informasi dari laporan-laporan pembukuan dan pertanggungjawaban pengelolaan dana. Kepala Madrasah menilai apakah dana sudah dialokasikan secara efetif dan efisien atau belum serta melihat apakah sesuai dengan yang telah di tetapkan dalam RKAM atau tidak. Selain itu, evaluasi digunakan untuk melihat kendala dalam pengelolaan dana untuk 
diberikan solusi-solusi agar lebih baik kedepannya. Seperti diungkapkan oleh Rusydi Ananda dan Tien Rafida, evaluasi pada hakikatnya adalah penyediaan informasi yang dapat dijadikan sebagai bahan pertimbangan dalam megambil keputusan (Ananda \& Rafida, 2017).

Jika hasil evaluasi menunjukkan hasil yang baik, maka pihak Madrasah hanya perlu mempertahankan atau mengembangkan program yang sudah ada. Namun jika hasil evaluasi menunjukkan hasil yang tidak baik, maka pihak Madrasah bisa mengambil keputusan terbaik untuk mengatasinya. Melalui evaluasi pembiayaan pendidikan, pihak sekolah akan mengetahui seberapa besar dana yang telah dihabiskan dalam anggaran tersebut serta akan diketahui apakah program pembiayaan pendidikan yang telah direncanakan dan yang telah diselenggarakan telah sesuai dengan yang diharapkan atau belum. Dan dengan evaluasi tersebut semua pembiayaan yang tersalurkan di lembaga pendidikan akan berjalan dengan semestinya.

\section{KESIMPULAN}

Berdasarkan hasil penelitian dan analisis yang sudah dilakukan terhadap implementasi manajemen pembiayaan pendidikan di MTs. Al-Manar Nurul Iman Sidamanik dapat diambil kesimpulan bahwa:

1. Perencanaan pembiayaan pendidikan di MTs. Al-Manar Nurul Iman Sidamanik dibuat pada Rencana Kegiatan dan Anggaran Madrasah (RKAM). Perencanaan pembiayaan dilakukan setiap bulan Januari dengan melibatkan Kepala Madrasah, Tata Usaha, Bendahara, Guruguru dan komite sekolah untuk membuat rancana anggaran selama satu tahun kedepan. Hasil rapat perencanaan biaya Madrasah yang telah selesai dibuat akan dikonsultasikan dengan pihak pengawas. Setelah disetujui, selanjutnya akan dilakukan pengusulan dana Bantuan Operasional Sekolah (BOS) dengan menyertakan Rencana Kegiatan dan Anggaran Madrasah (RKAM) kepada Kantor Wilayah Departemen Agama untuk dipertimbangkan dan disahkan.

2. Pelaksanaan pembiayaan pendidikan di MTs. Al-Manar Nurul Iman Sidamanik dana yang diperoleh bersumber dari dana Bantuan Operasional Sekolah (BOS) dan dana Komite. Dana Bantuan Operasional Sekolah (BOS) dialokasikan untuk gaji pendidik dan tenaga kependidikan sebesar 50\%, Sarana dan Prasarana sebesar 30\% dan untuk Alat Tulis Kantor (ATK) sebesar 20\%. Sedangkan untuk dana Komite, dialokasikan untuk tunjangan jabatan, kegiatan siswa, kebersihan sekolah, Alat Tulis Kantor (ATK), dan transport. 
Pengalokasian dana Bantuan Operasional Sekolah (BOS) dicatat di dalam Laporan Pertanggungjawaban (LPJ), sedangkan dana komite di catat di buku besar Uang SPP (Sumbangan Pembinaan Pendidikan) dan buku kas untuk pengalokasiannya. Yang bertanggungjawab terhadap pengalokasian seluruh dana adalah Kepala Madrasah. Dalam pelaksanaan pembiayaan pendidikan tidak selalu sesuai dengan perencanaan yang telah dibuat.

3. Pengawasan pembiayaan pendidikan di MTs. Al-Manar Nurul Iman Sidamanik dilakukan oleh dua pihak, yaitu pihak internal dan eksternal. Dari pihak internal ada Kepala Madrasah dan Komite sekolah, sedangkan dari pihak eksternal merupakan utusan dari Kantor Wilayah Departemen Agama Kabupaten Simalungun. Yang diawasi dalam pembiayaan pendidikan adalah pemasukan dan pengeluaran dana. Pengawasan dilakukan sesering mungkin oleh Kepala Madrasah dan Komite sekolah, namun untuk pengawasan dari Departemen Agama dilakukan kurang lebih empat kali dalam satu semester.

4. Evaluasi pembiayaan pendidikan di MTs. Al-Manar Nurul Iman Sidamanik dilakukan untuk manilai, memantau dan melaporkan apakah penggunaan anggaran sesuai dengan Rencana Kegiatan dan Anggaran Madrasah (RKAM) yang telah ditetapkan atau tidak. Evaluasi dilakukan oleh Kepala Madrasah secara berkala dalam kurun waktu yang telah ditetapkan, yaitu setiap tiga bulan sekali.

\section{DAFTAR PUSTAKA}

Akdon. (2015). Manajemen Pembiayaan Pendidikan. Remaja Rosdakarya.

Ananda, R., \& Rafida, T. (2017). Pengantar Evaluasi dan Program Pendidikan. Perdana Publishing.

Bafadal, I. (2013). Manajemen Peningkatan Mutu Sekoah Dasar dari Sentralisasi Menuju Desentralisasi. Bumi Aksara.

Djaali, \& Muljono, P. (2004). Pengukuran dalam Bidang Pendidikan. Universitas Negeri Jakarta.

Fattah, N. (2002). Ekonomi dan Pembiayaan Pendidikan. PT Remaja Rosdakarya.

Kurniadin, D., \& Machali, I. (2010). Manajemen Pendidikan. Ar-Ruuz Media.

Minarti, S. (2011). Manajemen Sekolah: Mengelola Lembaga Pendidikan Secara Mandiri. Ar Ruzz Media.

Mulyasa, E. (2009). Menjadi Kepala Sekolah Profesional. PT Remaja Rosdakarya. Mutrofin. (2010). Evaluasi Program, Teks Pilihan Untuk Pemula. Lakesbang Pressindo.

Nata, A. (2003). Manajemen Pendidikan: Mengatasi Kelemahan Pendidikan Islam di 
Journal Continuous Education

Volume 2, Issue 1, March 2021

Page 47-60

Indonesia, Bogor. Kencana.

Nawawi, \& Martini. (1996). Penelitian Terapan. Gadjah Madah University Press.

Rahmanto, S. (2019). Manajemen Pembiayaan Sekolah. Gre Publishing.

Sikdisnas. (2015). Peraturan Pemerintah Republik Indonesia No. 19 Tahun 2005

Tentang Standar Nasional Pendidikan Pasal 2 ayat 1.

Sugiyono. (2020). Metode Penelitian Pendidikan. Alfabeta.

Suryosubroto, B. (2010). Manajemen Pendidikan Sekolah. Rineka Cipta.

T. Hani Handoko. (2012). Manajemen. BPFE.

Terry, G. R., \& Rue, L. W. (2010). Dasar-dasar Manajemen. Bumi Aksara.

UU Republik Indonesia. (n.d.). Undang-Undang Nomor 17 Tahun 2003 Tentang Keuangan Negara Pasal 3 ayat 1. 